\title{
Culturable gut bacteria of Ikan Batak (Neolissochilus sumatranus Weber \& de Beaufort, 1916) collected in Toba Samosir, Indonesia
}

\author{
ACHMAD DINOTO`, RINI HANDAYANI, NINU SETIANINGRUM, HEDDY JULISTIONO \\ Microbiology Division, Research Center for Biology, Indonesian Institute of Sciences. Jl. Raya Jakarta-Bogor Km. 46, Cibinong Science Center, \\ Cibinong, Bogor 16911, West Java, Indonesia. Tel./fax.: +62-21-8765066/87907612, ^email: achmaddinoto@yahoo.com
}

Manuscript received: 23 July 2020. Revision accepted: 5 September 2020.

\begin{abstract}
Dinoto A, Handayani R, Setianingrum N, Julistiono H. 2020. Culturable gut bacteria of Ikan Batak (Neolissochilus sumatranus Weber \& de Beaufort, 1916) collected in Toba Samosir, Indonesia. Biodiversitas 21: 4483-4488. Ikan Batak (Neolissochilus sumatranus Weber \& de Beaufort, 1916) is one of the fish species that is rarely found in water and have the status of endangered species. In consequence, the loss of endemic fish may contribute to the loss of microorganisms that inhabits the fish as a host. The studies on microorganisms associated with $N$. sumatranus are very limited. Therefore, the purpose of this study was to isolate and identify the culturable bacteria isolated from the gut of $N$. sumatranus. Sampling of $N$. sumatranus was carried out in a river within Toba Samosir area which flows to Lake Toba. Fish gut content was collected for isolating microorganisms using three media, including MRS, 10X diluted MRS, and MRS supplemented with $1 \%$ bile salt. Thirteen isolates were successfully isolated and identified based on 16S rRNA. This study revealed various species of gut bacteria recovered from $N$. sumatranus based on BLAST analysis. The isolates showed closest relationship to species Bacillus subtilis (3 isolates), Bacillus tequilensis (2 isolates), Tumebacillus ginsengisoli (6 isolates), Klebsiella pneumoniae (1 isolate), and Lactobacillus pentosus (1 isolate) with the similarity ranging at 98.7 to $100 \%$. All $16 \mathrm{~S}$ rRNA gene nucleotides of isolates have been submitted to GenBank. This study also described the isolates that have a very close relationship with Bacillus tequilla and Bacillus subtilis. Further identification is challenged to obtain a big picture of the diversity of microorganisms and the functionality in the digestive ecosystem of $N$. sumatranus for their conservation and bioprospecting of microbial-based aquaculture.
\end{abstract}

Keywords: Bacillus, gut bacteria, Ikan Batak, Klebsiella, Lactobacillus, Neolissochilus sumatranus, Tumebacillus

\section{INTRODUCTION}

Ikan Batak (Neolissochilus sumatranus Weber \& de Beaufort, 1916) is an endemic fish of North Sumatra, especially in Lake Toba, and has been categorized as endangered (vulnerable) based on the IUCN Red List (Barus et al. 2014). Nowadays, most studies of $N$. sumatranus were focused on the phenotypic analysis, ecology, and behavior of fish (Purba et al. 2013; Roesma et al. 2019). Unfortunately, information on microbiological association of $N$. sumatranus is very limited, thus the association between microorganisms and fish adaptation and survival remains unclear. In addition, potential uses of microorganisms originated from endemic fish are also unexplored.

The presence of microbial communities in fish gut is associated with the ecology and physiology of the host. The particular importance with respect to host diet and digestion showing the functional relationships between fish intestinal communities and diet (Clements et al. 2014). The fish gut microbiota also plays critical roles in epithelial renewal and maturation, and regulate immune responses (Xiong et al. 2019). The structure and composition of gut microbiota, metabolic capacity, gut content, and enzyme activity are influenced by host trophic level (Liu et al. 2016). The meta-analysis study indicated that the trophic level, species habitat salinity, and possibly taxonomy variation is strongly correlated with the gut microbiota composition in fishes (Sullam et al. 2012; Wong and Rawls 2012).

Microbiota composition in several fish species in marine and freshwater has been reported previously. Phyla Proteobacteria, Bacteroides, Actinobacteria, Firmicutes, and Fusobacteria are commonly found in the gastrointestinal tract of freshwater fish (Romero et al. 2014). Fish bacteria could be distinguished with reference to dietary habits. Herbivorous fishes are inhabited mostly by cellulose-degrading bacteria species of Clostridium, Leptotrichia, and Citrobacter, while the carnivorous fishes are dominated by Cetobacterium spp. and proteaseproducing bacteria like Halomonas spp. (Liu et al. 2016). Study of the commercial warmwater fish showed the presence of Cetobacterium somerae, Plesiomonas shigelloides, Fusobacterium mortiferum, and Aeromonas spp. (Larsen et al. 2014). In addition, fish habitat also affects the variation in strain level. Comparative genomes of fish pathogenic Aeromonas isolated from different locations demonstrated the distribution of mobile elements, which is dependent on the host and geographic origin (Tekedar et al. 2019). In our previous study of fishoriginated bacteria in Indonesia, Weissella paramesenteroides was successfully isolated from Indonesian eels (Anguilla bicolor), in which this bacterium has potential properties of antimicrobials (Dinoto et al. 2018). Other local fishes are suggested to be microbial resources with unique properties. 
Although, several reports about microorganisms inhabiting the fish gut have been published, no report is available on gut microbes in $N$. sumatranus. The purpose of this study was to isolate and identify the gut bacteria of $N$. sumatranus. This study challenges the further description to obtain a big picture of the diversity of microorganisms and the functionality in the digestive ecosystem of $N$. sumatranus for their conservation and bioprospecting of microbial-based aquaculture.

\section{MATERIALS AND METHODS}

\section{Sample collection and bacterial isolation}

Sampling was conducted near Desa Bonandolok, Kecamatan Balige, Kabupaten Toba Samosir, North Sumatra province, Indonesia in February 2018. The fish was caught by fishnet in the river about three kilometers from preserved area for Ikan Batak (Neolissochilus sumatranus Weber \& de Beaufort, 1916) at Mual Sirambe Nauli. Only one fish was successfully collected in this river which is suggested to be out from the local conservation onto Lake Toba through the river stream. Gut content of fish was collected aseptically and the fish body was preserved in ethanol for the purpose of identification (Figure 1). Identification of fish was carried out in Museum Zoologicum Bogoriense (MZB) - LIPI (with professional support of Dr. Renny Kurnia Hadiaty). Fish gut content was inoculated into enriched broth media of de Man Rogosa and Sharpe broth (MRS) (Oxoid) in, ten times diluted MRS (1/10 MRS), and MRS supplemented with $1 \%$ (b/v) bile salts (MRS+bile) and incubated at room temperature for 48 days. Isolation of bacteria was conducted using serial dilution of $0.85 \% \mathrm{NaCl}$ solution onto the plate, consisting of agar media: MRS, 1/10 MRS, and MRS+bile). A single colony was collected and preserved in the glycerol medium at $-80^{\circ} \mathrm{C}$ deep freezer until use.

\section{Colony PCR amplification}

Colony PCR of purified bacterial isolate was performed using universal $16 \mathrm{~S}$ rDNA primers, $27 \mathrm{f}$ (5'AGAGTTTGATCCTGGCTCAG-3') and 1492r (5'GGTTACCTTGTTACGACTT-3'). The PCR reaction (50 $\mu \mathrm{L})$ consisted of $25 \mu \mathrm{L}$ GoTaq Green Master Mix (Promega), $1 \mu \mathrm{L} 1492 \mathrm{r}$ primer (10 $\mathrm{pM})$, and $1 \mu \mathrm{L} 27 \mathrm{f}$ primer $(10 \mathrm{pM})$, and a tiny amount of single bacterial colony. The PCR reaction was performed for 30 cycles using Takara Thermal Cycler Dice (Takara Co. Inc.) with the following conditions: $94^{\circ} \mathrm{C}$ for $5 \mathrm{~min}$ of predenaturation, $94^{\circ} \mathrm{C}$ for $1 \mathrm{~min}$ of denaturation, $55^{\circ} \mathrm{C}$ for 1 min of annealing, $72^{\circ} \mathrm{C}$ for $1 \mathrm{~min}$ of elongation and $72^{\circ} \mathrm{C}$ for $5 \mathrm{~min}$ of final extension. Visualization of PCR products was performed in gel electrophoresis agarose $1 \%$ with GelRed ${ }^{\circledR}$ Nucleic Acid Gel Stain (Biotium). The $1 \mathrm{~Kb}$ DNA ladder (Geneaid) was used to determine the size of PCR amplicon in the agarose gel. The sequencing of the $16 \mathrm{~S}$ rRNA (ribosomal ribonucleic acid) gene was conducted by First BASE Laboratories.

\section{Phylogeny analysis}

The 16S rRNA sequences were subsequently aligned with the multiple alignment method using Clustal $\mathrm{X}$ version 2.0 and BLAST (Basic Local Alignment Search Tool) analysis was performed with the database available at NCBI (https://blast.ncbi.nlm.nih.gov/Blast.cgi) on July 11, 2020. Clustal X version 2.0 software with neighbor-joining method of 1000 bootstraps was used to construct the phylogenetic trees.

\section{RESULTS AND DISCUSSION}

One sample of fish was successfully collected in the sampling area for one hundred meters along the river. A small fish (8 cm in length) was identified as Neolissochilus sumatranus. This study confirmed the presence of this species in Toba Samosir, North Sumatra, even though it was relatively rare. $N$. sumatranus was reported previously as endemic fish in North Sumatra freshwater, particularly in some of the rivers around the Asahan river and Lake Toba (Barus et al. 2014).
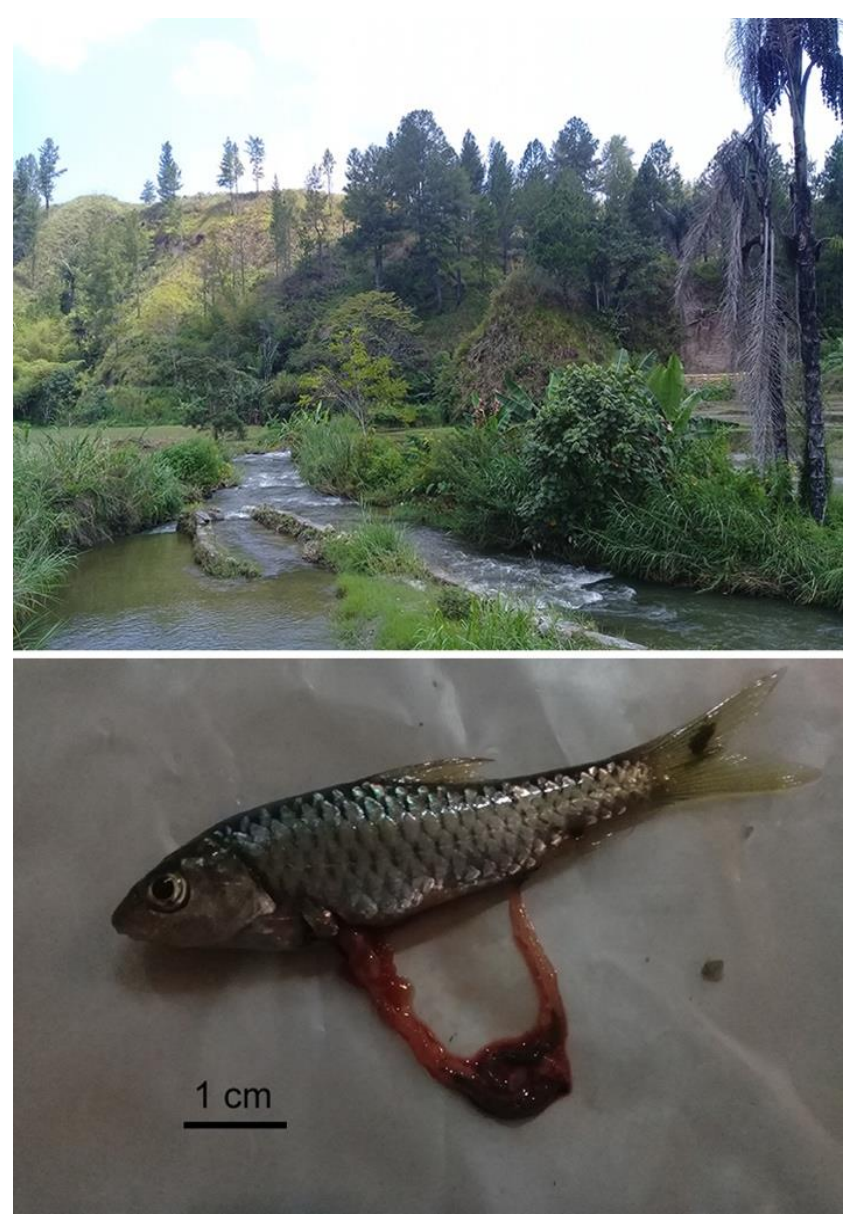

Figure 1. Sampling location at the river flowing to Lake Toba, North Sumatra, Indonesia (top) and a sample of Neolissochilus sumatranus (bottom) 
In the preliminary step, the fish gut content was enriched in broth media. We observed visually the high density of cell cultures in the tube after 48 days of incubation. Based on plate counts, the total cell number of enriched media was about $10^{6}$ to $10^{7} \mathrm{cfu} / \mathrm{ml}$. Actually, this total cell number was not representing bacterial population in the gut of $N$. sumatranus. The cell numbers suggested that gut bacteria could grow in the enriched media under aerobic conditions before the isolation process. A total of thirteen isolates with single colony were obtained after three times subculturing. Only isolates that grow well and demonstrated distinct morphological appearances were investigated further for taxonomical studies. PCR amplification of all isolates was successfully conducted showing the pattern at about $1500 \mathrm{bp}$ on the electrophoresis gel. As results, the contig sequences obtained from all isolates were about 1397-1419 bp in length, and they were sufficient to compare with the collection of rRNA sequences of the NCBI GenBank.
The BLAST analysis demonstrated that the similarity percentages of all isolates were 98.65 to $100 \%$ (Table 1). The phylogenetic analysis of 1000 bootstraps showed that 13 isolates are clustered in four different clades (Figure 1), including the clades of Bacillus spp. (5 isolates), Tumebacillus spp. (6 isolates), Lactobacillus sp. (1 isolate), and Klebsiella sp. (1 isolate) with the confidence level (over 500 bootstraps). The obtained nucleotide sequences were deposited in NCBI GenBank (ncbi.nlm.nih.gov) and assigned the following accession numbers of isolates as follows: MT4 (MT758358), MT6 (MT758359), MT9 (MT758360), MT10 (MT758361), BT2 (MT758362), BT3 (MT758363), BT4 (MT758364), DT1 (MT758365), DT3 (MT758366), DT6 (MT758367), DT7 (MT758368), DT8 (MT758369), and DT9 (MT758370). The profiles of the bacteria in the gut of $N$. sumatranus were previously not clearly known. As long as we knew, this study documented for the first time diversity of bacteria in the gut of $N$. sumatranus.

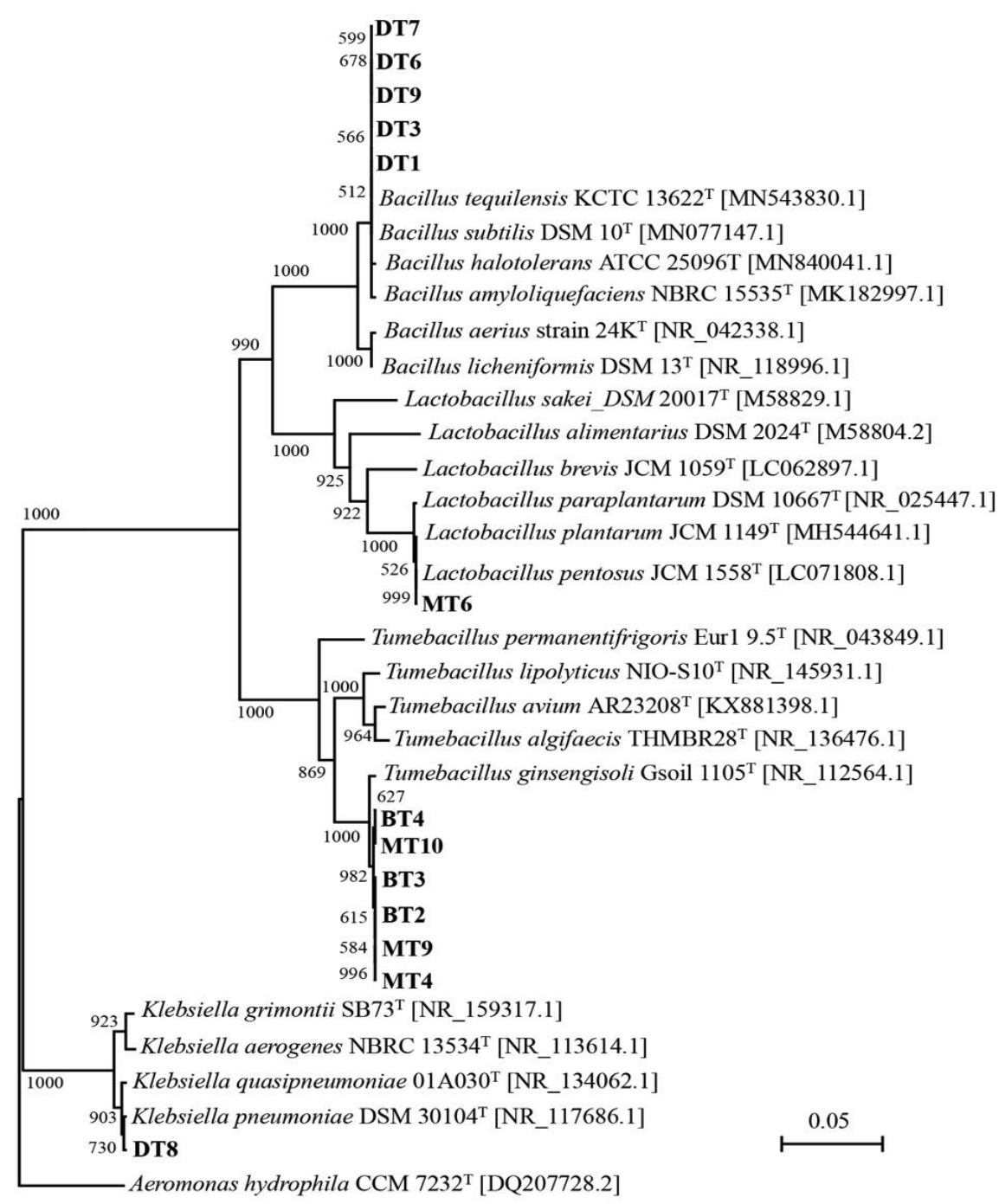

Figure 2. Phylogenetic tree of 16S rRNA sequences of isolates obtained from the gut of Neolissochilus sumatranus. Phylogenetic tree was constructed based on 16S rRNA gene sequencing by neighbor-joining method. Distances were estimated according to the Kimura two-parameter model with bootstrap percentages after 1000 simulations. Aeromonas hydrophila CCM $7372^{\mathrm{T}}$ was used as an outgroup 


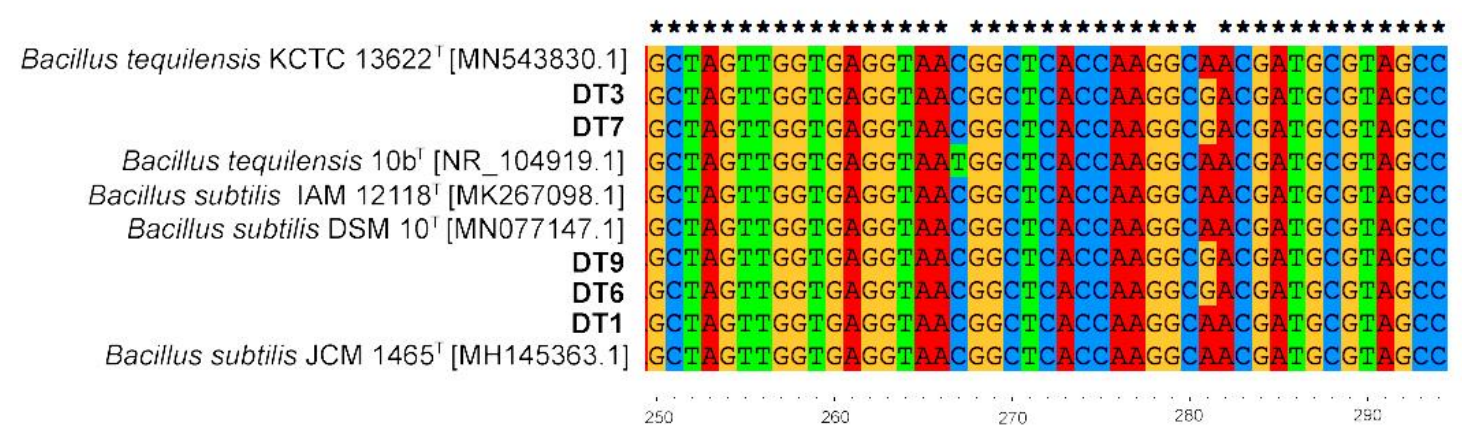

Figure 3. The 16S rRNA sequences alignment of isolates obtained from the gut of Neolissochilus sumatranus with representing type strain sequences of Bacillus tequilensis and Bacillus subtilis using clustalX

Table 1. BLAST results of $16 \mathrm{~S}$ rRNA gene of isolates obtained from gut of Neolissochilus sumatranus

\begin{tabular}{|c|c|c|c|}
\hline Isolate no. & $\begin{array}{l}\text { Sequence } \\
\text { length (bp) }\end{array}$ & Closest relationship [Accession No] & Similarity $(\%)$ \\
\hline MT4 & 1408 & Tumebacillus ginsengisoli Gsoil 1105 ${ }^{\mathrm{T}}$ [NR_112564.1] & 98.72 \\
\hline MT6 & 1418 & Lactobacillus pentosus JCM $1558^{\mathrm{T}}$ [LC071808.1] & 100.00 \\
\hline MT9 & 1415 & Tumebacillus ginsengisoli Gsoil 1105 [NR_112564.1] & 98.73 \\
\hline MT10 & 1397 & Tumebacillus ginsengisoli Gsoil 1105 ${ }^{\mathrm{T}}$ [NR_112564.1] & 98.78 \\
\hline BT2 & 1419 & Tumebacillus ginsengisoli Gsoil 1105 ${ }^{\mathrm{T}}$ [NR_112564.1] & 98.80 \\
\hline BT3 & 1415 & Tumebacillus ginsengisoli Gsoil 1105 ${ }^{\mathrm{T}}$ [NR_112564.1] & 98.80 \\
\hline BT4 & 1408 & Tumebacillus ginsengisoli Gsoil 1105 ${ }^{\mathrm{T}}$ [NR_112564.1] & 98.65 \\
\hline DT1 & 1397 & Bacillus subtilis DSM $10^{\mathrm{T}}$ [MN077147.1] & 100.00 \\
\hline DT3 & 1401 & Bacillus tequilensis $\mathrm{KCTC}^{\mathrm{T}} 13622^{\mathrm{T}}$ [MN543830.1] & 99.93 \\
\hline DT6 & 1411 & Bacillus subtilis DSM $10^{\mathrm{T}}$ [MN077147.1] & 99.86 \\
\hline DT7 & 1397 & Bacillus tequilensis $\mathrm{KCTC}^{\mathrm{T}} 13622^{\mathrm{T}}$ [MN543830.1] & 99.93 \\
\hline DT8 & 1406 & Klebsiella pneumoniae DSM $30104^{\mathrm{T}}\left[\mathrm{NR} \_117686.1\right]$ & 99.79 \\
\hline DT9 & 1400 & Bacillus subtilis DSM 10 ${ }^{\mathrm{T}}$ [MN077147.1] & 99.93 \\
\hline
\end{tabular}

Total of six isolates (MT4, MT9, MT10, BT2, BT3, and BT4) of bacterial collection had the closest relationship of 16S rRNA gene with Tumebacillus ginsengisoli (similarity of 98.65 to $98.80 \%$ ) (Table 1). Cells of $T$. ginsengisoli were observed microscopically as Gram-positive bacteria, aerobic, and non-motile rods. The type strain of this species, T. ginsengisoli Gsoil $1105^{\mathrm{T}}$ (= KCTC $13942^{\mathrm{T}}$, $=$ DSM $18389^{\mathrm{T}}$ ), was origin of the soil at a ginseng field in Pocheon Province, South Korea (Baek et al., 2011). The presence of $T$. ginsengisoli was interesting in the ecological perspective. Other species within genera Tumebacillus were reported on the aquatic environment. Tumebacillus flagellatus was isolated from cassava wastewater (Wang et al. 2013), whereas Tumebacillus lipolyticus was isolated from surface water (Prasad et al. 2015). Tumebacillus avium was previously reported in the gut of cinereous vulture, Aegypius monachus, however, the presence of this species in the gut of aquatic animals has not reported yet (Sung et al. 2018). This species is actually having broad distribution. Tumebacillus strain BK434 with a close relationship (99\%) with related to T. avium was the origin of roots (Carper et al. 2020). Accumulated knowledge of bacterial distribution in broad habitats and their adaptation is very limited. However, we assumed that $T$. ginsengisoli in the gut of fish as reported in this study is related to the linkage of the soil and water ecosystem, where $N$. sumatranus inhabiting freshwater environments.

This present study reported five isolates having similarities to the bacterial genus Bacillus (99.86 to $100 \%$ ). Three isolates (DT1, DT6, and DT9) were closest to $B$. subtilis. Another two species (DT3 and DT7) had the closest relationship with species Bacillus tequilensis (Table 1). Even isolate DT3 and DT7 having similarity with $B$. tequilensis (99.93\%), BLAST of $16 \mathrm{~S}$ rRNA gene sequences demonstrated very close relationship to $B$. subtilis $(99.86 \%$ similarity). Phylogenetic tree confirmed the close relationship of these strains at the same clade (Figure 2). Some variations in the alignment of representing 16S RNA nucleotides showed a close relationship (Figure 3). The phenomenon of very close relationship (99\%) within genus Bacillus was reported previously regarding the proposal of $B$. tequilensis as a novel species separated genetically from $B$. subtilis. Pulsed Field Gel Electrophoresis (PFGE) of type strain $10 \mathrm{~b}^{\mathrm{T}}$ revealed the restriction profile that distinguishes this strain from B. subtilis. DNA-DNA relatedness of strain $10 \mathrm{~b}^{\mathrm{T}}$ that was less than $70 \%$ with $B$. subtilis and other closely related species strongly support the species separation to novel species, B. tequilensis (Gatson et al. 2006). 
Originally, B. tequilensis type strain $10 \mathrm{~b}^{\mathrm{T}}(=\mathrm{ATCC}$ BAA $-819^{\mathrm{T}}=$ NCTC $13306^{\mathrm{T}}$ ) was isolated from 2000-yearold shaft-tomb at a site called Huitzilapa, near the city of Tequila in the Mexican state of Jalisco (Gatson et al. 2006). Our finding of the isolates that have the highest similarity to $B$. tequilensis in fish is not surprising, since this species may distribute in aquatic environment. Current publication reported a bacterium identified as $B$. tequilensis was successfully isolated from tilapia pond soil with the capacity of degrading unionized ammonia-nitrogen (Reyes et al. 2019). However, the presence of Bacillus in the gut of $N$. sumatranus was firstly documented in this study. $B$. subtilis is suggested to have broad distribution among various freshwater fish. Eight species in genera Bacillus have been found in the gut of guppy fish (Poecilia reticulata) including $B$. cereus, $B$. subtilis, $B$. amyloliquefaciens, B. licheniformis, B. altitudinis, $B$. megaterium, B. marisflavi, and B. anthracis (Kayath et al. 2019). The functionality of B. subtilis in aquaculture have been widely investigated. B. subtilis ZFB19 isolated from the gut of healthy grass carp showed antagonistic activity against Edwardsiella piscicida which was resistant to various antibiotics (Ren et al. 2019). Other studies also demonstrated the probiotic properties of B. subtilis in various aquatic animals, including grouper Epinephelus coioides (Liu et al. 2012) and white shrimp Litopenaeus vannamei (Zokaeifar et al. 2012). B. subtilis is suggested to be involved in controlling the fish pathogens by quorum sensing (QS) inhibition. Communication amongst the pathogenic Gram-negative bacteria by synthesizing, secreting, and responding to an autoinducer of QS systems-N-acyl-homoserine lactones (AHLs) were disturbed by AHL-lactonase, an enzyme catalyzing the degradation of the AHL. Previously, the expression of aiiA gene that encodes AHL-lactonase was reported in $B$. subtilis BS-1. The entire coding region of the gene of this species was successfully obtained by using the primer set AiiA1/AiiA2 in the PCR amplification (Pan et al. 2008). Using the same primer set, the aiiA gene was also recognized in other indigenous Bacillus isolated from Clarias gariepinus of Indonesia (Novita et al. 2015).

In this study, we reported the presence of one isolate related to $L$. pentosus ( $100 \%$ similarity). In general, $L$. pentosus is similar to L. plantarum, however, DNA-DNA hybridization demonstrated $36 \%$ to $85 \%$. In addition, $L$. pentosus could be distinguished from L. plantarum in producing acid from D-xylose and glycerol. The type strain of L. pentosus NCDO $363^{\mathrm{T}}$ (=ATCC 8041 ${ }^{\mathrm{T}}$ ) was originated from corn silage (Zanoni et al. 1987). Although genera Lactobacillus in the gut of freshwater fish has been previously reported (Romero et al. 2014), the presence of Lactobacillus pentosus in the gut of $N$. sumatranus was firstly reported in this study. Previously, L. pentosus PL11 has been isolated from gut of Japanese eels (Anguilla japonica). In addition, L. pentosus PL11 has been also characterized and evaluated for probiotic properties of production of digestive enzymes, bile and acid tolerance, adhesion to intestinal mucus, and antibacterial activity to inhibit fish pathogen (Lee et al. 2015). Specifically, $L$. pentosus PL11 demonstrated the immunomodulation of the inflammatory responses in fish owing to infection by pathogenic Edwardsiella tarda (Birhanu et al. 2016). Considering the species relativeness to previously published L. pentosus, the isolate MT6 is promising to be explored as probiotic agent in further research.

The 16S rRNA nucleotide of isolate DT8 was similar to Klebsiella pneumoniae (99.79\%). K. pneumoniae has been recognized as a cause of antibiotic-resistant bacterial infections in immunocompromised individuals. The type strain of this bacterium carried 5.54 Mb genome, in which several genes involved in the lactam resistance and toxin/ antitoxin roles (Daligault et al. 2014). In aquatic environments, $K$. pneumoniae has previously been reported as an opportunistic pathogen that causes fish infections. This species is aquatic-borne as observed in the tropical estuaries (Barati et al. 2016). In addition, K. pneumoniae was isolated in the infected farmed Indian major carp Labeo rohita (Das et al. 2018). We did not observe specifically the potential pathogenicity of isolate DT8 in this study, however, the isolate may be useful as indicator microorganisms for screening of antipathogenic biological agents.

Host ecology and environment is widely accepted to influence microbiota in the fish's gut (Wong and Rawls 2012). The manipulation of the fish microbiota may represent a new possibility in the prevention or management of pathological and physiological disorders (Thakur et al. 2014). Altogether, this study reflects that bacterial isolates from $N$. sumatranus are useful for further investigation of functional properties and bioprospecting to aquaculture.

\section{ACKNOWLEDGEMENTS}

This study was supported financially by DIPA from Research Center for Biology, Indonesian Institute of Sciences (LIPI), Cibinong, Bogor, Indonesia. The authors thank Jerry Silaen, Head of Fisheries Division, Agriculture and Fisheries Office of Toba Samosir, and his staffs for helping the fish sample collection.

\section{REFERENCES}

Baek SH, Cui Y, Kim SC, Cui CH, Yin C, Lee ST, Im WT. 2011. Tumebacillus ginsengisoli sp. nov., isolated from soil of a ginseng field. Intl J Syst Evol Microbiol 61: 1715-1719.

Barati A, Ghaderpour A, Chew LL, Bong CW, Thong KL, Chong VC, Chai LC. 2016. Isolation and characterization of aquatic-borne Klebsiella pneumoniae from tropical estuaries in Malaysia. Intl J Environ Res Public Health 13(4): 426.

Barus TA, Wahyuningsih H, Ginting EM, Ph C. 2014. Ecobiological review of Neolissochilus sumatranus (Ikan Batak) (Weber and de Beaufort, 1916) in Asahan River, North Sumatera. In: Proceeding of The First International Seminar on Trends in Science and Science Education, Medan, 2014. [Indonesian]

Birhanu BT, Lee JS, Lee SJ, Choi SH, Hossain MA, Park JY, Kim JC, Suh JW, Park SC. 2016. Immunomodulation of Lactobacillus pentosus PL11 against Edwardsiella tarda infection in the head kidney cells of the Japanese eel (Anguilla japonica). Fish Shellfish Immunol 54: 466-472.

Carper DL, Schadt CW, Burdick LH, Kalluri UC, Pelletier A. 2020. Draft genome sequence of Tumebacillus sp. strain BK434, isolated from the 
roots of Eastern Cottonwood. Microbiol Resour Announcements 9: e00351-20. DOI: 10.1128/MRA.00351-20.

Clements KD, Angert ER, Montgomery WL, Choat JH. 2014. Intestinal microbiota in fishes: What's known and what's not. Mol Ecol 23: 1891-1898.

Daligault HE, Davenport KW, Minogue TD, Bishop-Lilly KA, Bruce DC, Chain PS, Coyne SR, Frey KG, Jaissle J, Koroleva GI, Ladner JT, Lo CC, Meincke L, Munk AC, Palacios GF, Redden CL, Johnson SL. 2014. Draft genome assembly of Klebsiella pneumoniae type strain ATCC 13883. Genome Announcements 2: 4-5.

Das A, Acharya S, Behera BK, Paria P, Bhowmick S, Parida PK, Das BK. 2018. Isolation, identification and characterization of Klebsiella pneumoniae from infected farmed Indian Major Carp Labeo rohita (Hamilton 1822) in West Bengal, India. Aquaculture 482: 111-116.

Dinoto A, Sulistiani S, Suswati S, Handayani R, Julistiono H,. 2018. Weissella paramesenteroides from intestine of Indonesian eel (Anguilla bicolor McClelland) and their potential antimicrobial property. AIP Conf Proc. DOI: 10.1063/1.5062799.

Gatson JW, Benz BF, Chandrasekaran C, Satomi M, Venkateswaran K, Hart ME. 2006. Bacillus tequilensis sp. nov., isolated from a 2000 year-old Mexican shaft-tomb, is closely related to Bacillus subtilis. Intl J Syst Evol Microbiol 56: 1475-1484.

Kayath CA, Ibala Zamba A, Goma-Tchimbakala J, Mamonékéné V, Mombo Makanga GM, Lebonguy AA, Nguimbi E. 2019. Microbiota landscape of gut system of guppy fish (Poecilia reticulata) plays an outstanding role in adaptation mechanisms. Intl J Microbiol 2019: 3590584. DOI: 10.1155/2019/3590584.

Larsen AM, Mohammed HH, Arias CR. 2014. Characterization of the gut microbiota of three commercially valuable warm water fish species. J Appl Microbiol 116: 1396-1404.

Lee JS, Damte D, Lee SJ, Hossain MA, Belew S, Kim JY, Rhee MH, Kim JC, Park SC. 2015. Evaluation and characterization of a nove probiotic Lactobacillus pentosus PL11 isolated from Japanese eel (Anguilla japonica) for its use in aquaculture. Aquac Nutr 21: 444 456.

Liu $\mathrm{CH}$, Chiu CH, Wang SW, Cheng W. 2012. Dietary administration of the probiotic, Bacillus subtilis E20, enhances the growth, innate immune responses, and disease resistance of the grouper, Epinephelus coioides. Fish Shellfish Immunol 33: 699-706.

Liu H, Guo X, Gooneratne R, Lai R, Zeng C, Zhan F, Wang W. 2016. The gut microbiome and degradation enzyme activity of wild freshwater fishes influenced by their trophic levels. Sci Rep 6: 24340. DOI: 10.1038/srep24340.

Novita H, Rusmana I, Yuhana M, Pasaribu FH. 2015. Karakterisasi bakteri anti quorum sensing (AQS) sebagai penghambat virulensi penyakit pada ikan lele dumbo (Clarias gariepinus). J Ris Akuakultur 10: 89. [Indonesian]

Pan J, Huang T, Yao F, Huang Z, Powell CA, Qiu S, Guan X. 2008. Expression and characterization of aiiA gene from Bacillus subtilis BS-1. Microbiol Res 163: 711-716
Prasad R V., Bhumika V, Anil Kumar P, Srinivas NRT. 2015. Tumebacillus lipolyticus sp. nov., isolated from river water. Intl J Syst Evol Microbiol 65: 4363-4368.

Purba M, Barus TA, Ilyas S. 2013. Hubungan antara kualitas air dengan kebiasaan makanan Ikan Batak (Neolissochilus sumatranus) di Sungai Asahan, Sumatera Utara. J Biosains 1: 21-28. [Indonesian]

Ren X, Wu B, Zhao F, Qi L, Qiu X, Li R, Yang S, Liu F, Yi G, Ding X, Xia L, Sun Y. 2019. Antagonistic activity and protective effect of a Bacillus subtilis isolate against fish pathogen Edwardsiella piscicida. Fish Sci 85: 1011-1018.

Reyes AT, Jorduela EL, Doctolero JS. 2019. Bacillus tequilensis, a novel unionized ammonia-nitrogen degrading bacterium isolated from tilapia pond soil. Intl J Fish Aquat Stud 7: 161-165.

Roesma ID, Chornelia A, Mursyid A. 2019. Phenotype analysis of endemic mahseer fish (Neolissochilus sumatranus) from Batang Toru tributaries, North Sumatra, Indonesia. IOP Conf Ser J Phys 1317: 012099. DOI: 10.1088/1742-6596/1317/1/012099.

Romero J, Ring $\varnothing$ E, Merrifield DL. 2014. The gut microbiota of fish. In: Merrifield D, Ringo E (eds.). Aquaculture Nutrition: Gut Health, Probiotic and Prebiotics. John Wiley \& Sons, Ltd., Chichester.

Sullam KE, Essinger SD, Lozupone CA, Connor MPO. 2012. Environmental and ecological factors that shape the gut bacterial communities of fish: a meta-analysis. Mol Ecol 21: 3363-3378.

Sung H, Kim HS, Lee JY, Kang W, Kim PS, Hyun DW, Tak EJ, Jung MJ, Yun JH, Kim MS, Shin NR, Whon TW, Rho JR, Park SD, Shim HE, Bae JW. 2018. Tumebacillus avium sp. nov., isolated from the gut of a cinereous vulture, Aegypius monachus. Intl J Syst Evol Microbiol 68: 1659-1664.

Tekedar HC, Kumru S, Blom J, Perkins AD, Griffin MJ, Abdelhamed H, Lawrence ML. 2019. Comparative genomics of Aeromonas veronii: Identification of a pathotype impacting aquaculture globally. PloS One 14 (8): e0221018. DOI: 10.1371/journal.pone.0221018.

Thakur AK, Shakya A, Mohammed G. 2014. Gut-microbiota and mental health: current and future perspectives. J Pharmacol Clin Toxicol 2: 1016.

Wang Q, Xie N, Qin Y, Shen N, Zhu J, Mi H, Huang R. 2013. Tumebacillus flagellatus sp. nov., an $\alpha$-amylase/pullulanaseproducing bacterium isolated from cassava wastewater. Intl J Syst Evol Microbiol 63: 3138-3142.

Wong S, Rawls JF. 2012. Intestinal microbiota composition in fishes is influenced by host ecology and environment. Mol Ecol 21: 31003102 .

Xiong JB, Nie L, Chen J. 2019. Current understanding on the roles of gut microbiota in fish disease and immunity. Zool Res 40: 70-76.

Zanoni P, Farrow JAE, Phillips BA, Collins MD. 1987. Lactobacillus pentosus (Fred, Peterson, and Anderson) sp. nov., norn, rev. Intl J Syst Bacteriol 37: 339-341.

Zokaeifar H, Balcázar JL, Saad CR, Kamarudin MS, Sijam K, Arshad A, Nejat N. 2012. Effects of Bacillus subtilis on the growth performance, digestive enzymes, immune gene expression and disease resistance of white shrimp, Litopenaeus vannamei. Fish Shellfish Immunol 33: 683-689. 